\title{
A kálium, bór és stroncium kezelés hatása a koronafürtre (Coronilla varia $\mathrm{L}$.)
}

\author{
KÁDÁR Imre \\ MTA ATK Talajtani és Agrokémiai Intézet, Budapest
}

\section{Bevezetés}

A koronafürt évelö pillangósvirágú takarmánynövény, a Fabaceae (Hüvelyesek) család tagja. Magyarországon őshonos, elterjedt Közép- és DK- Európában, valamint Közép-Ázsiában. Nálunk réteken, legelökön, kopárosokon és árokszélen gyakori. Sokáig gyomként kezelték és mérgezőnek tartották. Az 1950-es évek elején az USA-ban felkarolták. Az USA-ba a lucerna gyomnövényként került Európából, majd onnan kultúrnövényként került vissza (MÁTÉ, 1983 a,b,c).

A növény gyengébb talajokon is $5-6 \mathrm{t} \cdot \mathrm{ha}^{-1} \cdot \mathrm{é}^{-1}$ szénatermést adhat a lucernával azonos vagy hasonló nyersfehérje- és nyersrost-tartalommal. Szárazságtürő és télálló. Betegségei és kártevői gyakorlatilag nincsenek, az aranka nem támadja meg. Hosszú élettartamú, legeltethető juhokkal, kecskékkel és marhákkal. Türi a rágást, tiprást és nem okoz felfúvódást. Biztos magtermő $0,5 \mathrm{t} \cdot \mathrm{ha}^{-1}$ hozammal és a házi méhek is megtermékenyítik (BóCSA et al., 1980; BóCSA, 1994; ANTAL, 2000). Kiváló talajerózió-gátló növény. Az USA-ban (Pennsylvania) már 1947-ben telepítették autópálya rézsükre. Kidolgozták a koronafürt termesztés agrotechnikáját és vizsgálták a növény talaj- és tápanyagigényét, ( $\mathrm{pH}$, talajkötöttség, nedvesség, tápelem-ellátottság stb.) (GRACE \& GRAU 1952; HENSON, 1963; SHEARD, 1971). Ma már szinte minden államban termelik. Hátránya hogy az első évben nem ad kielégítő termést, mert a kezdeti fejlődése lassú. Kelése kb. egy hónapot vesz igénybe, ugyanakkor kiváló nyári legelö, amikor a gyepek már kiégtek. Toxikus $\beta$-nitropropionsavat tartalmaz, amely azonban a kérődzők bendőjében elbomlik.

A növény megél a meleg, száraz déli lejtökön, nem való a pangóvizes, nedves területekre, futóhomokra és szikesekre. Mint a többi pillangós, föként mész- és foszforigényes kultúra.

Magyarországon MÁTÉ (1983 a,b,c) vizsgálta a koronafürt talajigényét. Megállapította, hogy a savanyú homokon meszezés nélkül nem telepíthetö, mert kipusztul. A termésnövelés szempontjából meghatározó a P-trágyázás, mert a gyenge Pellátottságú talajon a koronafürt rövidéletü lehet.

Postai cím: KÁDÁR IMRE, MTA Agrártudományi Kutatóközpont, Talajtani és Agrokémiai Intézet, 1022 Budapest, Herman Ottó út 15., Email: kadar@rissac.hu 
A szerző szabadföldi és tenyészedény-kísérleteket is végzett és igazolta, hogy kötöttebb humuszosabb talajokon a $\mathrm{N}$ és $\mathrm{K}$ érdemi hatást nem gyakorol a koronafürt termésére.

Jelen munkánkban, tartamkísérletünk 14-17. éveiben, a KxBxSr trágyázás hatását vizsgáltuk a koronafürt termésére és összetételére. Hasonló vizsgálatok hazánkban ezzel a növénnyel még nem folytak. Az első évben napraforgót termesztettünk. A B-trágyázás tőszámcsökkenést okozott, melyet a K-trágyázással ellensúlyozni lehetett. A második évben termesztett kukorica szem-és szártermése $1,5 \mathrm{t} \cdot \mathrm{ha}^{-1}$-al lett kisebb a maximális B-terhelés hatására. A termésdepresszió, illetve mérgezés akkor következett be, amikor a 4-6 leveles hajtás B-koncentrációja a $40 \mathrm{~kg} \cdot \mathrm{ha}^{-1} \mathrm{~B}$-adagnál elérte a $70-80$, a virágzáskori levélben pedig a $100 \mathrm{mg} \cdot \mathrm{kg}^{-1}$ határértéket. A Kfeltöltés részben ellensúlyozta a B-toxicitást. A harmadik évben a $\mathrm{K}$ - és a Bkezelések nem befolyásolták a tavaszi repce fejlődését, termését. A megismételt Kés B-terhelési szintek sem módosították a lucerna termését 2001-2004 között és cirok termését sem 1995-ben. A növények elemösszetétele viszont változott (KÁDÁR, 2011, 2012; KÁDÁR \& CSATHÓ 2011, 2012).

\section{Vizsgálati anyag és módszer}

A K és B elemek közötti kölcsönhatásokat vizsgáló kísérletet 1987 öszén állítottuk be az MTA TAKI Nagyhörcsöki Kísérleti Telepén. A kísérlet talaja löszön képződött, vályog fizikai féleségü mészlepedékes csernozjom, amely $5 \% \mathrm{CaCO}_{3}$-ot, $3 \%$ humuszt és $20 \%$ agyagot tartalmaz a szántott rétegben. A talajvíz szintje 13-15 m mélyen található, a terület aszályérzékeny. Éghajlata az Alföldéhez hasonlóan szárazságra hajló, átlagos középhőmérséklete $11^{\circ} \mathrm{C}$, az éves csapadékösszeg általában 400-600 mm között ingadozik.

Az 1987 öszén végzett talajvizsgálatok eredménye szerint a feltalaj kémhatása $\mathrm{pH}\left(\mathrm{H}_{2} \mathrm{O}\right) 7,8$; illetve $\mathrm{pH}(\mathrm{KCl}) 7,3$; az AL- $\mathrm{K}_{2} \mathrm{O}$ : 180-200; AL- $\mathrm{P}_{2} \mathrm{O}_{5:}$ 100-120; KCloldható $\mathrm{Mg}$ : $110-150 ; \mathrm{KCl}+$ EDTA oldható $\mathrm{Mn}$ : 60-80, a Cu és $\mathrm{Zn:} 1-2$ és a B: 0,7 $\mathrm{mg} \cdot \mathrm{kg}^{-1}$ értékekkel volt jellemezhető. A MÉM NAK (1979) által elfogadott módszerek és határértékek alapján ezek az adatok a talaj kielégítö Mn-, B-, Mg- és K-, közepes N- és P-, valamint gyenge Zn- és Cu-ellátottságról tanúskodnak.

A kísérlet osztott parcellás (split-plot) elrendezésú, a beállításkor $3 \mathrm{Kx} 4 \mathrm{~B}=12$ kezeléssel és három ismétlésben, összesen 36 parcellával. A parcellák mérete 4,9 x $8=39,2 \mathrm{~m}^{2}$ volt. A parcellákat 1992 tavaszán megfeleztük és az így nyert fél parcellákon $67 \mathrm{~kg} \cdot \mathrm{ha}^{-1} \mathrm{Sr}$-ot szórtunk ki $\mathrm{SrCl}_{2} \times 6 \mathrm{H}_{2} \mathrm{O}$ formájában. A 4B x $3 \mathrm{~K}$ x $2 \mathrm{Sr}=$ 24 kezelés $x 3$ ismétlés $=72$ parcellát eredményezett, ahol a BxKxSr elemek közötti kölcsönhatások is vizsgálhatókká váltak.

A kísérlet tényezői:

1. tényezö (föparcellák): K

$\mathrm{K}_{0}=$ kontroll

$\mathrm{K}_{1}=1000 \mathrm{~kg} \mathrm{~K}_{2} \mathrm{O} \cdot \mathrm{ha}^{-1} 1987$ és 1990 öszén kiadva

$\mathrm{K}_{2}=2000 \mathrm{~kg} \mathrm{~K}_{2} \mathrm{O} \cdot \mathrm{ha}^{-1}, 1987$ és 1990 öszén kiadva

2. tényező (alparcellák): B 
$\mathrm{B}_{0}=$ kontroll

$\mathrm{B}_{1}=20 \mathrm{~kg} \mathrm{~B} \cdot \mathrm{ha}^{-1}, 1988$ tavasz és 1990 öszén kiadva

$\mathrm{B}_{2}=40 \mathrm{~kg} \mathrm{~B} \cdot \mathrm{ha}^{-1}, 1988$ tavaszán és 1990 öszén kiadva

$\mathrm{B}_{3}=60 \mathrm{~kg} \mathrm{~B} \cdot \mathrm{ha}^{-1}, 1988$ tavaszán és 1990 öszén kiadva

3. tényező (al-alparcellák): Sr

$\mathrm{Sr}_{0}=$ kontroll

$\mathrm{Sr}_{1}=67 \mathrm{~kg} \mathrm{Sr} \cdot \mathrm{ha}^{-1} 1992$ tavaszán kiadva

A tartamkísérlet 1988 és 2004 között folyt, 17 éven át. A kísérlet beállításának körülményeiről és az első hét évben kapott eredményekről korábbi munkánk számol be (KÁDÁR, 2012).

A növényi sorrendet az 1. táblázat tekinti át, feltüntetve a termesztett növényfajokat, fajtákat, illetve hibrideket is az egyes években. Megemlítjük, hogy az alaptrágyázás általában $100-100 \mathrm{~kg} \cdot$ ha $^{-1} \cdot \mathrm{év}^{-1} \mathrm{~N}$ és $\mathrm{P}_{2} \mathrm{O}_{5}$ volt $25 \%$-os pétisó és szuperfoszfát formájában. A lucerna $\mathrm{N}$-trágyázásban nem részesült. A telepítést megelőzően $400 \mathrm{~kg} \cdot \mathrm{ha}^{-1} \mathrm{P}_{2} \mathrm{O}_{5}$-adagot adtuk ki a négy évre. Kálisóként $60 \%$-os KCl-ot, bórtrágyaként $11,3 \%$-os bóraxot $\mathrm{Na}_{2} \mathrm{~B}_{4} \mathrm{O}_{7} \times 10 \mathrm{H}_{2} \mathrm{O}$ használtunk.

\section{1. táblázat}

A KxBxSr tartamkísérlet növényi sorrendje 1988 és 2004 között

(Mészlepedékes csernozjom vályogtalaj, Nagyhörcsök, Mezöföld)

\begin{tabular}{|c|l|l|c|l|l|}
\hline $\begin{array}{c}\text { Kísérlet } \\
\text { éve }\end{array}$ & $\begin{array}{c}\text { Növényfaj } \\
\text { (forgó) }\end{array}$ & $\begin{array}{c}\text { Fajta } \\
\text { (hibrid) }\end{array}$ & $\begin{array}{c}\text { (1) } \\
\text { Kísérlet } \\
\text { éve }\end{array}$ & $\begin{array}{c}\text { (2) } \\
\text { Növényfaj } \\
\text { (forgó) }\end{array}$ & $\begin{array}{c}\text { (3) } \\
\text { Fajta } \\
\text { (hibrid) }\end{array}$ \\
\hline 1988 & napraforgó & Topflor-2 & 1996 & búza & MV-21 \\
1989 & kukorica & Pi 3732 & 1997 & bab & Debreceni tarka \\
1990 & tavaszi repce & Arista & 1998 & mák & Kompolti-M \\
1991 & lucerna & Verko & 1999 & öszi árpa & Botond \\
1992 & lucerna & Verko & 2000 & tritikále & Presto \\
1993 & lucerna & Verko & 2001 & koronafürt & Kompolti tarka \\
1994 & lucerna & Verko & 2002 & koronafürt & Kompolti tarka \\
1995 & cirok & Alföldi-1 & 2003 & koronafürt & Kompolti tarka \\
& & & 2004 & koronafürt & Kompolti tarka \\
\hline
\end{tabular}

A betakarítást követően parcellánként 20 -20 pontból eseti jelleggel átlagmintákat vettünk a szántott talajrétegből. A talajmintákat $40-50 \mathrm{C}^{\mathrm{o}}$-on szárítottuk, majd homogenizáltuk és az analízisre előkészítettük. A talajok alapvizsgálati jellemzőit BARANYAI és munkatársai (1987), illetve a MÉM NAK (1978) által ismertetett eljárásokkal határoztuk meg. Az ammóniumlaktát + ecetsav oldható P- és Ktartalmakat EGNÉR és munkatársai (1960), a humusztartalmat pedig TYURIN (1937) módszere szerint határoztuk meg. 


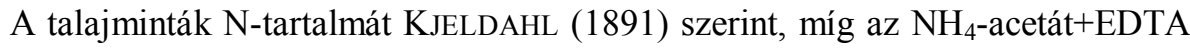
oldható elemtartalmát LAKANEN és ERVIÖ (1971) módszerével vizsgáltuk a kísérlet egyes éveiben. A növénymintákat a hagyományos cc. $\mathrm{HNO} 3+c c . \mathrm{H}_{2} \mathrm{O}_{2}$-os roncsolást követően elemeztük - a B kivételével - ICP-OES berendezéssel (Yobin-Yvon, Longjumeau, Franciaország). A B vizsgálatát a talajban és a növényekben az azomethine-H módszerrel végeztük SIPPOLA és ERVIÖ (1977), illetve SILlANPäÄ (1982) leírása alapján. A fehérjék aminosav-összetételét sósavas hidrolízis után STEIN és MoORE (1951) módszerével Biotronik LC 3000-es készülékkel (Biotronik Gmbh, Hanau, Németország) GYöRI (1999) szerint határoztuk meg.

A koronafürt vetése 2001. május 2-án történt $1-2 \mathrm{~cm}$ mélyre, $24 \mathrm{~cm}$ sortávra, $120 \mathrm{db} \cdot \mathrm{fm}^{-1}$, illetve $15 \mathrm{~kg} \cdot \mathrm{ha}^{-1}$ vetőmagnormával a Kompolton kiadott Telepítési Útmutató szerint (ANONYM, 1985). Az aszályos május folyamán a feltalaj teljesen kiszáradt, a magvak nem csíráztak ezért június végén újravetésre került sor.

A kísérletben végzett föbb agrotechnikai műveletekről és a vonatkozó módszertani megjegyzésekről a 2. táblázat nyújt áttekintést.

\section{2. táblázat}

Főbb agrotechnikai műveletek és megfigyelések a tarka koronafürt kísérletben, 2001-2004

(Mészlepedékes csernozjom vályogtalaj, Nagyhörcsök, Mezőföld)

\begin{tabular}{|c|c|c|}
\hline $\begin{array}{c}\text { (1) } \\
\text { Müveletek megnevezése }\end{array}$ & $\begin{array}{c}\text { (2) } \\
\text { Időpont }\end{array}$ & $\begin{array}{l}\text { (3) } \\
\text { Egyéb megjegyzés }\end{array}$ \\
\hline $\begin{array}{l}\text { a) Öszi mütrágyázás }(\mathrm{N}, \mathrm{P}) \\
\text { b) Őszi mélyszántás }(25-30 \mathrm{~cm})\end{array}$ & $\begin{array}{l}2000.09 .14 \text {. } \\
2000.09 .14\end{array}$ & $\begin{array}{l}\text { Parcellánként kézzel } \\
\text { MTZ-50+Lajta eke }\end{array}$ \\
\hline c) Tavaszi N-mütrágyázás & 2001.03.12. & Parcellánként kézzel \\
\hline d) Fogasolás, mütrágya bedolgozása & 2001.03.12. & MTZ-50+fogas \\
\hline e) Vetőágykészítés & 2001.05 .02 . & MTZ-50+kombinátor \\
\hline f) Vetés+hengerezés & 2001.05 .02$. & $\begin{array}{l}\text { MTZ-50+Lajta vetö- } \\
\text { gép+simahenger }\end{array}$ \\
\hline g) Vetés+hengerezés (újravetve) & 2001.06 .25 . & $\begin{array}{l}\text { MTZ-50+Lajta vetö- } \\
\text { gép+simahenger }\end{array}$ \\
\hline h) Bonitálás fejlettségre & 2001.11.05. & Parcellánként $1-5$ skálán \\
\hline i) Kaszálás (fükasza) & 2001.11.05. & Parcellánként $4,9 \times 2,1=10,3 \mathrm{~m}^{2}$ \\
\hline j) Minták szárítása, darálása & 2001.12.20. & Parcellánkénti átlagminták \\
\hline
\end{tabular}

Megjegyzés: Kompolti tarka koronafürt 1-2 cm mélyre vetve $24 \mathrm{~cm}$ sortávra, $120 \mathrm{db} \cdot \mathrm{fm}^{-1}$, illetve $15 \mathrm{~kg} \cdot \mathrm{ha}^{-1}$ vetőmag mennyiséggel

Az állományt bonitáltuk fejlettségre, majd fükaszával takarítottuk be a 4,9×2,1= $10,3 \mathrm{~m}^{2}$ parcellánkénti nettó területről. A lekaszált anyagból átlagmintát vettünk, parcellánként 20-20 helyről véletlenszerüen gyüjtve 1-1 marokkal.

Mértük az átlagminták friss, majd a légszáraz tömegét és a durva, illetve finom örlés (homogenizálás) után a laboratóriumba szállítottuk analízisre a 72 db örleményt. 


\section{3. táblázat}

A havi és éves csapadékösszegek a 2000 és 2004 közötti években, mm (Mészlepedékes csernozjom vályogtalaj, Nagyhörcsök, Mezőföld)

\begin{tabular}{|c|c|c|c|c|c|c|}
\hline \multirow{2}{*}{$\begin{array}{c}\text { Vizsgált } \\
\text { hónapok }\end{array}$} & \multicolumn{5}{|c|}{$\begin{array}{c}(2) \\
\text { Vizsgált évek }\end{array}$} & $\begin{array}{c}\text { (3) } \\
\text { Sokéves } \\
\text { átlag* }\end{array}$ \\
\cline { 2 - 6 } & 2000 & 2001 & 2002 & 2003 & 2004 & 29 \\
I. & 31 & 44 & 11 & 29 & 32 & 29 \\
II. & 19 & 0 & 18 & 34 & 46 & 32 \\
III. & 32 & 62 & 14 & 5 & 61 & 43 \\
IV. & 53 & 47 & 41 & 22 & 88 & 46 \\
V. & 20 & 17 & 55 & 30 & 28 & 71 \\
VI. & 10 & 47 & 32 & 18 & 113 & 56 \\
VII. & 44 & 80 & 64 & 88 & 38 & 60 \\
VIII. & 11 & 129 & 84 & 25 & 26 & 47 \\
IX. & 43 & 113 & 65 & 27 & 17 & 41 \\
X. & 32 & 0 & 32 & 92 & 59 & 53 \\
XI. & 34 & 57 & 32 & 39 & 58 & 41 \\
XII. & 57 & 25 & 28 & 16 & 41 & 540 \\
ässesen & 384 & 622 & 476 & 425 & 607 & \\
\hline
\end{tabular}

Megjegyzés:* A kísérleti telepen mért 48 éves átlag

Csapadékellátottság: az elővetemény tritikále kiszárította a talajt, de a betakarítását követően a 2000 év második felében még $221 \mathrm{~mm}$, majd a koronafürt újravetéséig 2001-ben $217 \mathrm{~mm}$ eső hullott a növénnyel lényegében nem fedett talajra. Az így számított $438 \mathrm{~mm}$ csapadék feltölthette e vályogtalaj $1 \mathrm{~m}$ rétegének $160 \mathrm{~mm}$ hasznosítható (DV) vízkészletét. Az újravetést követően júliusban 80, augusztusban 129 , szeptemberben 113 és októberben $0 \mathrm{~mm}$ csapadékban részesült a terület, tehát a jó négyhónapos tenyészidő alatt az 1 . kaszálás idejéig $322 \mathrm{~mm}-\mathrm{t}$ kapott.

A 2000-2004. évek havi és éves csapadékösszegeit, valamint összevetésképpen a kísérleti telepen mért 48 éves átlag adatait a 3. táblázat foglalja össze. A 2000. év csapadékban szegény volt, míg a 2001. és a 2004. év viszonylag gazdag.

\section{Vizsgálati eredmények}

A koronafürt hozamait tekintve az első évben 1, a következö években 2-2 kaszálásra került sor.

A legnagyobb átlagos szénatermést, $6 \mathrm{t} \cdot \mathrm{ha}^{-1}$ légszáraz tömeggel, a 2. év 1. vágása produkálta. Legkisebb szénatermést az 1 . évben nyertük $1,9 \mathrm{t} \cdot \mathrm{ha}^{-1}$ mennyiséggel. A zöldtermés átlaga 10-28 $\mathrm{t} \cdot \mathrm{ha}^{-1}$ között változott ugyanezekben az időkben. A 4. táblázatban az is megfigyelhető, hogy a talaj javuló K-kínálatával - tendenciájában vagy igazolhatóan - emelkedett a zöld és a szénatermés tömege, míg a légszárazanyag \%-a mérséklődött. 
4. táblázat

K-ellátottság hatása a koronafürt termésére kaszálásonként (Mészlepedékes csernozjom vályogtalaj, Nagyhörcsök, Mezőföld)

\begin{tabular}{|c|c|c|c|c|c|c|c|c|}
\hline \multirow{2}{*}{$\frac{\mathrm{AL}-\mathrm{K}_{2} \mathrm{O}^{*}}{\mathrm{mg} \cdot \mathrm{kg}^{-1}}$} & \multirow{2}{*}{$\begin{array}{r}2001 \\
11.05 .\end{array}$} & \multicolumn{2}{|c|}{2002} & \multicolumn{2}{|c|}{2003} & \multicolumn{2}{|c|}{2004} & \multirow{2}{*}{$\begin{array}{l}\text { (1) } \\
\text { Összesen } \\
\text { hét vágás }\end{array}$} \\
\hline & & 06.03 . & 08.22 . & 06.03 . & 09.23 . & 05.19 . & 07.09 . & \\
\hline \multicolumn{9}{|c|}{ A. Zöld termés, $t \cdot h a^{-1}$} \\
\hline 140 & 9 & 26 & 9 & 11 & 2 & 21 & 22 & 100 \\
\hline 184 & 10 & 28 & 10 & 12 & 3 & 25 & 24 & 112 \\
\hline 227 & 10 & 30 & 10 & 14 & 3 & 27 & 26 & 120 \\
\hline a) $\mathrm{SzD}_{5 \%}$ & 1 & 2 & 1 & 2 & 1 & 3 & 2 & 6 \\
\hline b) Átlag & 10 & 28 & 10 & 12 & 3 & 24 & 24 & 111 \\
\hline \multicolumn{9}{|c|}{ B. Légszárazanyag, \% } \\
\hline 140 & 20 & 22 & 23 & 28 & 38 & 16 & 19 & 24 \\
\hline 184 & 19 & 22 & 22 & 27 & 38 & 15 & 18 & 23 \\
\hline 227 & 18 & 21 & 21 & 26 & 37 & 15 & 17 & 22 \\
\hline a) $\mathrm{SzD}_{5 \%}$ & 1 & 1 & 1 & 1 & 1 & 1 & 1 & 1 \\
\hline b) Átlag & 19 & 22 & 22 & 27 & 38 & 15 & 18 & 23 \\
\hline \multicolumn{9}{|c|}{ C. Légszáraz széna, $t \cdot h a^{-1}$} \\
\hline 140 & 1,9 & 5,8 & 2,0 & 3,0 & 0,9 & 3,4 & 4,1 & 21,1 \\
\hline 184 & 1,9 & 6,1 & 2,1 & 3,2 & 1,0 & 3,7 & 4,2 & 22,2 \\
\hline 227 & 1,9 & 6,2 & 2,1 & 3,5 & 1,2 & 4,0 & 4,5 & 24,4 \\
\hline a) $\mathrm{SzD}_{5 \%}$ & 0,2 & 0,6 & 0,1 & 0,6 & 0,2 & 0,4 & 0,4 & 0,8 \\
\hline b) Átlag & 1,9 & 6,0 & 2,1 & 3,2 & 1,1 & 3,7 & 4,3 & 22,3 \\
\hline
\end{tabular}

Megjegyzés: * az AL-oldható $\mathrm{K}_{2} \mathrm{O}$ tartalom vizsgálata 2000-ben (szántott réteg)

Ismert, hogy a $\mathrm{K}$ fiatalít, növeli a vízfelvételt és a szárazságtürést egyaránt. Úgy tünik a koronafürt K-igényes, hiszen a $200 \mathrm{mg} \cdot \mathrm{kg}^{-1}$ feletti $\mathrm{AL}-\mathrm{K}_{2} \mathrm{O}$ tartalomra is terméstöbblettel reagálhat. Az aratáskori állomány légszárazanyag-tartalma igen tág határok között, 15-38\% között ingadozott az egyes kaszálások idején. A friss termés hozama a négy év, illetve hét kaszálás összegében $110-120 \mathrm{t} \cdot \mathrm{ha}^{-1}$, a szénahozam 21-24 $\mathrm{t} \cdot \mathrm{ha}^{-1}$ (átlagosan 22,3 $\mathrm{t} \cdot \mathrm{ha}^{-1}$ ) mennyiséget tett ki.

A talaj K-kínálata nemcsak a termésre hatott, hanem az egyéb vizsgált kationok beépülésére is a szénában. A K-tartalom minden kaszálás szénájában látványosan emelkedett. A 2. kaszálás elöregedő, 38\% légszárazanyag-tartalmú anyagában $1 \%$ alá csökkent a K-kontroll talajon, de a K-trágyázással 1,63\%-ra emelkedett.

A maximális, 3,22\%-os K-tartalmat 2002-ben az 1. kaszáláskor mértük a fiatal állományban, a legnagyobb K-ellátottságú parcellákon. Itt lecsökkent az antagonista Ca mennyisége 1,51\%-ra, míg az említett elöregedő, K-szegény állományban 2003. szeptember 23-án 4,19\%-ra emelkedett (5. táblázat). A Mg-koncentrációja szintén mérséklődött a K-kínálattal, a kalciumhoz hasonlóan az elöregedő szénában dúsult $0,8 \%$ fölé, míg a fiatal 1 . kaszálású állomány szénájában $0,3 \%$ alatt maradt. Az átlagos $\mathrm{K} / \mathrm{Ca}$ arány a fiatal szénában 1,5 , a $\mathrm{K} / \mathrm{Mg}$ arány 9,0 volt. Az elöregedő széna $\mathrm{K} / \mathrm{Ca}$ aránya 0,3 , a $\mathrm{K} / \mathrm{Mg}$ aránya pedig 1,7 volt. 
A K-túlsúly mértéke a széna élettani korát jellemzi, a fiatal aktív vízbő szövetek meglétét. Megnyilvánult a $\mathrm{K}-\mathrm{Na}$ antagonizmus is, a növekvő K-kínálattal a széna $\mathrm{Na}$-tartalma rendre visszaszorult. Hasonló jelenség volt megfigyelhető meg a $\mathrm{K}$ és Sr kationok viszonylatában.

A Sr a Ca kísérőeleme kőzetekben, ásványokban és az élö szövetekben egyaránt. Ebből kifolyólag szintén jellemezheti az állomány élettani állapotát. A fiatal szénában $50-60 \mathrm{mg} \cdot \mathrm{kg}^{-1}$ körüli mennyiségben, míg az elöregedő állományban 150 és 160 $\mathrm{mg} \cdot \mathrm{kg}^{-1}$ közötti Sr-tartalmat találtunk (5. táblázat).

\section{5. táblázat}

K-ellátottság hatása a légszáraz tarka koronafürt K-, Ca-, Mg-, Na- és Sr-tartalmára (Mészlepedékes csernozjom vályogtalaj, Nagyhörcsök, Mezőföld)

\begin{tabular}{|c|c|c|c|c|c|c|c|}
\hline $\mathrm{AL}-\mathrm{K}_{2} \mathrm{O}$ & 2001 & \multicolumn{2}{|c|}{2002} & \multicolumn{2}{|c|}{2003} & \multicolumn{2}{|c|}{2004} \\
\hline $\mathrm{mg} \cdot \mathrm{kg}^{-1}$ & 1. vágás & 1. vágás & 2. vágás & 1. vágás & 2. vágás & 1. vágás & 2. vágás \\
\hline \multicolumn{8}{|c|}{$K, \%$} \\
\hline 140 & 1,90 & 1,75 & 1,88 & 1,44 & 0,86 & 1,88 & 1,55 \\
\hline 184 & 2,55 & 2,32 & 2,45 & 1,72 & 1,14 & 2,28 & 2,02 \\
\hline 227 & 3,08 & 3,22 & 3,03 & 2,20 & 1,63 & 2,80 & 2,68 \\
\hline a) $\mathrm{SzD}_{5 \%}$ & 0,10 & 0,11 & 0,24 & 0,16 & 0,32 & 0,48 & 0,17 \\
\hline b) Átlag & 2,51 & 2,43 & 2,45 & 1,79 & 1,21 & 2,32 & 2,09 \\
\hline \multicolumn{8}{|c|}{$\mathrm{Ca}, \%$} \\
\hline 140 & 3,09 & 1,78 & 3,16 & 1,78 & 4,19 & 1,77 & 2,08 \\
\hline 184 & 2,45 & 1,55 & 3,17 & 1,76 & 4,09 & 1,61 & 2,02 \\
\hline 227 & 1,88 & 1,51 & 2,93 & 1,60 & 3,84 & 1,55 & 1,83 \\
\hline a) $\mathrm{SzD}_{5 \%}$ & 0,25 & 0,22 & 0,24 & 0,44 & 0,22 & 0,20 & 0,16 \\
\hline b) Átlag & 2,47 & 1,61 & 3,09 & 1,72 & 4,04 & 1,64 & 1,97 \\
\hline \multicolumn{8}{|c|}{$M g, \%$} \\
\hline 140 & 0,38 & 0,29 & 0,58 & 0,32 & 0,84 & 0,23 & 0,31 \\
\hline 184 & 0,33 & 0,29 & 0,51 & 0,28 & 0,72 & 0,22 & 0,28 \\
\hline 227 & 0,26 & 0,24 & 0,42 & 0,25 & 0,61 & 0,21 & 0,23 \\
\hline a) $\mathrm{SzD}_{5 \%}$ & 0,05 & 0,04 & 0,05 & 0,07 & 0,09 & 0,02 & 0,05 \\
\hline b) Átlag & 0,32 & 0,27 & 0,50 & 0,28 & 0,72 & 0,22 & 0,27 \\
\hline \multicolumn{8}{|c|}{$\mathrm{Na}, \mathrm{mg} \cdot \mathrm{kg}^{-1}$} \\
\hline 140 & 35 & 19 & 38 & 16 & 9 & 9 & 16 \\
\hline 184 & 24 & 9 & 38 & 15 & 5 & 10 & 10 \\
\hline 227 & 15 & 9 & 38 & 10 & 7 & 8 & 14 \\
\hline a) $\mathrm{SzD}_{5 \%}$ & 6 & 4 & 2 & 6 & 2 & 3 & 5 \\
\hline b) Átlag & 25 & 12 & 38 & 14 & 7 & 9 & 14 \\
\hline \multicolumn{8}{|c|}{$\mathrm{Sr}, \mathrm{mg} \cdot \mathrm{kg}^{-1}$} \\
\hline 140 & 98 & 56 & 99 & 60 & 164 & 55 & 74 \\
\hline 184 & 95 & 60 & 92 & 58 & 154 & 51 & 70 \\
\hline 227 & 92 & 54 & 86 & 55 & 150 & 50 & 64 \\
\hline a) $\mathrm{SzD}_{5 \%}$ & 6 & 6 & 9 & 5 & 9 & 6 & 6 \\
\hline b) Átlag & 95 & 56 & 92 & 58 & 156 & 52 & 69 \\
\hline
\end{tabular}


6. táblázat

B-kezelések hatása a légszáraz tarka koronafürt B-tartalmára, $\mathrm{mg} \cdot \mathrm{kg}^{-1}$

(Mészlepedékes csernozjom vályogtalaj, Nagyhörcsök, Mezőföld)

\begin{tabular}{|c|c|c|c|c|c|c|c|}
\hline $\begin{array}{c}(1) \\
\text { B-adag, } \\
\mathrm{kg} \cdot \text { ha }^{-1}\end{array}$ & 2001 & \multicolumn{2}{|c|}{2002} & \multicolumn{2}{c|}{2003} & \multicolumn{2}{c|}{2004} \\
\cline { 2 - 8 } & 1. vágás & 1. vágás & 2. vágás & 1. vágás & 2. vágás & 1. vágás & 2. vágás \\
\hline 0 & 23 & 25 & 32 & 26 & 50 & 22 & 42 \\
40 & 50 & 36 & 48 & 42 & 100 & 41 & 66 \\
80 & 70 & 48 & 75 & 82 & 239 & 72 & 170 \\
160 & 89 & 54 & 89 & 100 & 372 & 95 & 209 \\
a) $\mathrm{SzD}_{5 \%}$ & 12 & 6 & 12 & 19 & 84 & 10 & 33 \\
b) Átlag & 58 & 41 & 61 & 62 & 190 & 57 & 122 \\
\hline
\end{tabular}

A B-trágya szemmel láthatóan igen hatásos volt még a bevitel után 10-15 évvel is. A trágyázatlan talajon 22 és $50 \mathrm{mg} \cdot \mathrm{kg}^{-1} \mathrm{közötti} \mathrm{a} \mathrm{széna} \mathrm{B-tartalma,} \mathrm{míg} \mathrm{a} \mathrm{maxi-}$ mális B-terhelésủ talajon $54-372 \mathrm{mg} \cdot \mathrm{kg}^{-1}$ tartományban változott, igen széles sávban. Megfigyelhető volt az a törvényszerüség, hogy a 2. vágású, idősebb állomány halmozza fel a nagyobb mennyiséget. Az elöregedö, 2003. szeptember 23 -án aratott szénában extrém nagy akkumuláció jelentkezett. A kis termés betöményedett, érvényesült az úgynevezett „,koncentrációs effektus”. A koronafürt B-türése kiváló, hisz termésdepresszió nélkül képes ilyen mennyiségü B-t felhalmozni (6. táblázat).

Ismert, hogy a kétszikúek B-készlete nagyobb, mint az egyszikűeké. A pillangósok különösen B-igényesek. A B-igényes növénynek genetikailag nagyobb a Btürése a B-mérgezéssel és a B-akkumulációval szemben. Kérdés, hogy a legelő állatok mennyiben viselik el a hasonló B-terhelést, mely bélgyulladást, végtagbénulást okozhat emberben és állatban. Esszencialitása egyértelmüen nem bizonyított emberre és állatra, toxicitása viszont igen.

A Sr-trágyázás a növény Sr-tartalmát a 9-12. év után igazolhatóan már nem növelte. A Sr-trágyázás hatása kimutatható volt viszont a $\mathrm{Sr}-\mathrm{Na}$ kation antagonizmus eredményeképpen a Na-csökkentő effektus tendenciájában vagy statisztikailag is igazolhatóan (7. táblázat).

\section{7. táblázat}

A Sr-kezelés hatása a légszáraz tarka koronafürt Na-tartalmára, $\mathrm{mg} \cdot \mathrm{kg}^{-1}$ (Mészlepedékes csernozjom vályogtalaj, Nagyhörcsök, Mezőföld)

\begin{tabular}{|c|c|c|c|c|c|c|c|}
\hline $\begin{array}{c}(1) \\
\text { Sr-adag }\end{array}$ & 2001 & \multicolumn{2}{|c|}{2002} & \multicolumn{2}{c|}{2003} & \multicolumn{2}{c|}{2004} \\
\hline $\mathrm{kg} \cdot$ ha $^{-1}$ & 1. vágás & 1. vágás & 2. vágás & 1. vágás & 2. vágás & 1. vágás & 2. vágás \\
\hline 0 & 30 & 10 & 37 & 18 & 9 & 10 & 17 \\
67 & 20 & 14 & 39 & 9 & 5 & 8 & 12 \\
a) $\mathrm{SzD}_{5 \%}$ & 7 & 5 & 2 & 5 & 2 & 3 & 4 \\
b) Átlag & 25 & 12 & 38 & 14 & 7 & 9 & 14 \\
\hline
\end{tabular}


8. táblázat

A légszáraz tarka koronafürt átlagos összetétele kaszálásonként (Mészlepedékes csernozjom vályogtalaj, Nagyhörcsök, Mezőföld)

\begin{tabular}{|c|c|c|c|c|c|c|c|c|}
\hline \multirow{2}{*}{$\begin{array}{l}\text { (1) } \\
\text { Elem } \\
\text { jele }\end{array}$} & \multirow{2}{*}{$\begin{array}{c}\text { (2) } \\
\text { Mérték- } \\
\text { egység }\end{array}$} & \multirow[b]{2}{*}{$\begin{array}{l}2001 \\
\text { 1. vágás }\end{array}$} & \multicolumn{2}{|c|}{2002} & \multicolumn{2}{|c|}{2003} & \multicolumn{2}{|c|}{2004} \\
\hline & & & $\begin{array}{c}1 . \\
\text { vágás }\end{array}$ & $\begin{array}{c}2 . \\
\text { vágás }\end{array}$ & $\begin{array}{c}1 . \\
\text { vágás }\end{array}$ & $\begin{array}{c}2 . \\
\text { vágás }\end{array}$ & $\begin{array}{c}1 . \\
\text { vágás }\end{array}$ & $\begin{array}{c}2 . \\
\text { vágás }\end{array}$ \\
\hline $\mathrm{N}$ & $\%$ & 3,71 & 2,81 & 3,74 & 3,29 & 3,97 & 3,84 & 3,42 \\
\hline $\mathrm{K}$ & $\%$ & 2,51 & 2,43 & 2,45 & 1,79 & 1,21 & 2,32 & 2,09 \\
\hline $\mathrm{Ca}$ & $\%$ & 2,47 & 1,61 & 3,09 & 1,72 & 4,04 & 1,64 & 1,97 \\
\hline $\mathrm{P}$ & $\%$ & 0,38 & 0,33 & 0,34 & 0,30 & 0,17 & 0,46 & 0,34 \\
\hline $\mathrm{Mg}$ & $\%$ & 0,32 & 0,27 & 0,50 & 0,28 & 0,72 & 0,22 & 0,27 \\
\hline $\mathrm{S}$ & $\%$ & 0,21 & 0,21 & 0,31 & 0,32 & 0,56 & 0,30 & 0,23 \\
\hline $\mathrm{Fe}$ & $\mathrm{mg} \cdot \mathrm{kg}^{-1}$ & 434 & 294 & 168 & 153 & 475 & 164 & 60 \\
\hline $\mathrm{Al}$ & $\mathrm{mg} \cdot \mathrm{kg}^{-1}$ & 398 & 188 & 115 & 94 & 486 & 72 & 23 \\
\hline Mn & $\mathrm{mg} \cdot \mathrm{kg}^{-1}$ & 137 & 43 & 104 & 50 & 156 & 50 & 52 \\
\hline $\mathrm{Sr}$ & $\mathrm{mg} \cdot \mathrm{kg}^{-1}$ & 95 & 56 & 92 & 58 & 156 & 52 & 69 \\
\hline $\mathrm{Na}$ & $\mathrm{mg} \cdot \mathrm{kg}^{-1}$ & 25 & 12 & 38 & 14 & 7 & 9 & 14 \\
\hline $\mathrm{B}$ & $\mathrm{mg} \cdot \mathrm{kg}^{-1}$ & 23 & 22 & 42 & 26 & 50 & 25 & 32 \\
\hline $\mathrm{Zn}$ & $\mathrm{mg} \cdot \mathrm{kg}^{-1}$ & 15 & 12 & 18 & 14 & 13 & 18 & 16 \\
\hline $\mathrm{Cu}$ & $\mathrm{mg} \cdot \mathrm{kg}^{-1}$ & 7 & 6 & 8 & 6 & 6 & 7 & 6 \\
\hline $\mathrm{Ba}$ & $\mathrm{mg} \cdot \mathrm{kg}^{-1}$ & 6 & 3 & 7 & 4 & 9 & 3 & 5 \\
\hline $\mathrm{Ni}$ & $\mathrm{mg} \cdot \mathrm{kg}^{-1}$ & 1,36 & 1,14 & 0,10 & 3,32 & 0,71 & 2,52 & 1,27 \\
\hline Mo & $\mathrm{mg} \cdot \mathrm{kg}^{-1}$ & 0,65 & 0,72 & 0,53 & 1,15 & 0,29 & 1,29 & 0,80 \\
\hline $\mathrm{Cr}$ & $\mathrm{mg} \cdot \mathrm{kg}^{-1}$ & 0,58 & 0,37 & 0,52 & 0,31 & 0,56 & 1,12 & 0,10 \\
\hline $\mathrm{Pb}$ & $\mathrm{mg} \cdot \mathrm{kg}^{-1}$ & 0,55 & 0,99 & 0,75 & 0,44 & 0,56 & $<0,10$ & $<0,10$ \\
\hline $\mathrm{Co}$ & $\mathrm{mg} \cdot \mathrm{kg}^{-1}$ & 0,20 & 0,14 & 0,15 & 0,12 & 0,18 & 0,13 & 0,07 \\
\hline $\mathrm{Cd}$ & $\mathrm{mg} \cdot \mathrm{kg}^{-1}$ & 0,12 & 0,08 & $<0,10$ & 0,10 & $<0,10$ & 0,08 & 0,08 \\
\hline $\mathrm{Se}$ & $\mathrm{mg} \cdot \mathrm{kg}^{-1}$ & $<0,10$ & $<0,10$ & $<0,10$ & $<0,10$ & $<0,10$ & $<0,10$ & $<0,10$ \\
\hline As & $\mathrm{mg} \cdot \mathrm{kg}^{-1}$ & $<0,10$ & $<0,10$ & $<0,10$ & $<0,10$ & $<0,10$ & $<0,10$ & $<0,10$ \\
\hline $\mathrm{Hg}$ & $\mathrm{mg} \cdot \mathrm{kg}^{-1}$ & $<0,10$ & $<0,10$ & $<0,10$ & $<0,10$ & $<0,10$ & $<0,10$ & $<0,10$ \\
\hline $\begin{array}{l}\mathrm{NO}_{3^{-}} \\
\mathrm{N}\end{array}$ & $\mathrm{mg} \cdot \mathrm{kg}^{-1}$ & 3,03 & - & - & - & - & - & 2,60 \\
\hline
\end{tabular}

A szénát kaszálásonként 6 makro- és 18 mikroelemre vizsgáltuk. Két ízben a $\mathrm{NO}_{3}-\mathrm{N}$ koncentrációit is meghatároztuk (8. táblázat). A táblázatban látható hogy a N 2,8-4,0\% között ingadozhat, a P $0,17-0,46 \%$-ot, a S pedig $0,21-0,56 \%$-ot érhet el. A koronafürt a pillangós takarmányokhoz hasonlóan tehát gazdag $\mathrm{N}, \mathrm{K}, \mathrm{Ca}, \mathrm{Mg}$, P és S elemekben. A vizsgált mikroelemek közül a Mn 43-156, a Zn 12-18, a Ba $3-9$, a Ni $0,10-3,32$, a Mo $0,29-1,29$ és a $\mathrm{Cr} 0,10-1,12 \mathrm{mg} \cdot \mathrm{kg}^{-1}$ koncentrációtartományban ingadozott. $\mathrm{A} \mathrm{NO}_{3}-\mathrm{N} 2,6-3,0 \mathrm{mg} \cdot \mathrm{kg}^{-1}$ volt, tehát a széna kedvezően kevés mennyiséget akkumulált.

A lucerna optimális összetétele kaszálások idején, zöldbimbós állapotban az alábbi lehet BERGMANN (1992) és SimKINS (1970) szerint: N: 2-5; K: 2-4; Ca: 1-3; Mg: 0,3-0,8; illetve a P és S 0,3-0,7\%. Ami a mikroelemeket illeti, a Fe és az Al 
30-200, a Mn 30-100, a B 35-80, a Zn 20-70, a Cu 5-15 és a Mo 0,5-2,0 mg $\cdot \mathrm{kg}^{-1}$ lehet. Úgy tünik, a lucernára megállapított diagnosztikai ellátottsági határkoncentrációk alkalmasak lehetnek a hasonló fejlődési stádiumban található koronafürtre is. A lucerna optimumait korábban ellenőriztük kísérleteinkben (KÁDÁR, 2009).

A tápelemfelvétel maximuma a 2. év 1. kaszálásában jelentkezett 2002-ben, amikor a $6 \mathrm{t} \cdot \mathrm{ha}^{-1}$ szénával $169 \mathrm{~kg} \mathrm{~N}, 146 \mathrm{~kg} \mathrm{~K}\left(175 \mathrm{~kg} \mathrm{~K}{ }_{2} \mathrm{O}\right) 97 \mathrm{~kg} \mathrm{Ca}(136 \mathrm{~kg}$ $\mathrm{CaO}), 20 \mathrm{~kg} \mathrm{P}\left(45 \mathrm{~kg} \mathrm{P}_{2} \mathrm{O}_{5}\right)$ és $16 \mathrm{~kg} \mathrm{Mg}(27 \mathrm{~kg} \mathrm{MgO})$ mennyiségével szegényedett a talaj. A $\mathrm{N}$ ez alól kivételével, melyet alapvetően a levegőböl kötött meg a növény és a visszamaradó gyökér N-készletével a talaj humusz és N-készlete gyarapodhat.

\section{9. táblázat}

A tarka koronafürt átlagos légszáraz termése és elemfelvétele kaszálásonként (Mészlepedékes csernozjom vályogtalaj, Nagyhörcsök, Mezőföld)

\begin{tabular}{|c|c|c|c|c|c|c|c|c|c|}
\hline \multirow{2}{*}{$\begin{array}{l}\text { (1) } \\
\text { Elem } \\
\text { jele }\end{array}$} & \multirow{2}{*}{$\begin{array}{c}(2) \\
\text { Mérték- } \\
\text { egység }\end{array}$} & \multirow{2}{*}{$\begin{array}{c}2001 \\
1 . \\
\text { vágás }\end{array}$} & \multicolumn{2}{|c|}{2002} & \multicolumn{2}{|c|}{2003} & \multicolumn{2}{|c|}{2004} & \multirow{2}{*}{$\begin{array}{c}\text { (3) } \\
\text { Együtt } \\
\text { hét } \\
\text { vágás }\end{array}$} \\
\hline & & & $\begin{array}{c}1 . \\
\text { vágás }\end{array}$ & $\begin{array}{c}2 . \\
\text { vágás }\end{array}$ & $\begin{array}{c}1 . \\
\text { vágás }\end{array}$ & $\begin{array}{c}2 . \\
\text { vágás }\end{array}$ & $\begin{array}{c}1 . \\
\text { vágás }\end{array}$ & $\begin{array}{c}2 . \\
\text { vágás }\end{array}$ & \\
\hline Széna & $\mathrm{t} \cdot \mathrm{ha}^{-1}$ & 1,9 & 6,0 & 2,1 & 3,2 & 1,1 & 3,7 & 4,3 & 22,3 \\
\hline $\mathrm{N}$ & $\mathrm{kg} \cdot \mathrm{ha}^{-1}$ & 70 & 169 & 79 & 105 & 44 & 142 & 147 & 756 \\
\hline K & $\mathrm{kg} \cdot \mathrm{ha}^{-1}$ & 48 & 146 & 51 & 57 & 13 & 86 & 90 & 491 \\
\hline $\mathrm{Ca}$ & $\mathrm{kg} \cdot \mathrm{ha}^{-1}$ & 47 & 97 & 65 & 55 & 44 & 61 & 85 & 454 \\
\hline $\mathrm{P}$ & $\mathrm{kg} \cdot \mathrm{ha}^{-1}$ & 7 & 20 & 7 & 10 & 2 & 17 & 15 & 78 \\
\hline $\mathrm{Mg}$ & $\mathrm{kg} \cdot \mathrm{ha}^{-1}$ & 6 & 16 & 10 & 9 & 8 & 8 & 12 & 69 \\
\hline $\mathrm{S}$ & $\mathrm{kg} \cdot \mathrm{ha}^{-1}$ & 4 & 13 & 7 & 10 & 6 & 11 & 10 & 61 \\
\hline $\mathrm{Fe}$ & $\mathrm{g} \cdot \mathrm{ha}^{-1}$ & 825 & 1764 & 353 & 490 & 522 & 607 & 258 & 4819 \\
\hline $\mathrm{Al}$ & $\mathrm{g} \cdot \mathrm{ha}^{-1}$ & 756 & 1128 & 242 & 301 & 535 & 266 & 99 & 3327 \\
\hline $\mathrm{Mn}$ & $\mathrm{g} \cdot \mathrm{ha}^{-1}$ & 260 & 258 & 218 & 160 & 172 & 185 & 224 & 1477 \\
\hline $\mathrm{Sr}$ & $\mathrm{g} \cdot \mathrm{ha}^{-1}$ & 180 & 336 & 193 & 186 & 172 & 192 & 297 & 1556 \\
\hline $\mathrm{Na}$ & $\mathrm{g} \cdot \mathrm{ha}^{-1}$ & 48 & 72 & 80 & 45 & 8 & 33 & 60 & 346 \\
\hline $\mathrm{B}$ & $\mathrm{g} \cdot \mathrm{ha}^{-1}$ & 44 & 132 & 88 & 83 & 55 & 92 & 138 & 632 \\
\hline $\mathrm{Zn}$ & $\mathrm{g} \cdot \mathrm{ha}^{-1}$ & 28 & 72 & 38 & 45 & 14 & 67 & 69 & 333 \\
\hline $\mathrm{Cu}$ & $\mathrm{g} \cdot \mathrm{ha}^{-1}$ & 13 & 36 & 17 & 19 & 7 & 26 & 26 & 144 \\
\hline $\mathrm{Ba}$ & $\mathrm{g} \cdot \mathrm{ha}^{-1}$ & 11 & 18 & 15 & 13 & 10 & 11 & 22 & 100 \\
\hline $\mathrm{Ni}$ & $\mathrm{g} \cdot \mathrm{ha}^{-1}$ & 2,6 & 6,8 & $<0,2$ & 10,6 & 0,8 & 9,3 & 5,5 & 35,6 \\
\hline Mo & $\mathrm{g} \cdot \mathrm{ha}^{-1}$ & 1,2 & 4,3 & 1,1 & 3,7 & 0,3 & 4,8 & 3,4 & 18,8 \\
\hline $\mathrm{Cr}$ & $\mathrm{g} \cdot \mathrm{ha}^{-1}$ & 1,1 & 2,2 & 1,1 & 1,0 & 0,6 & 4,1 & $<0,2$ & 10,1 \\
\hline $\mathrm{Pb}$ & $\mathrm{g} \cdot \mathrm{ha}^{-1}$ & 1,0 & 5,9 & 1,6 & 1,4 & 0,6 & $<0,2$ & $<0,2$ & 10,5 \\
\hline Co & $\mathrm{g} \cdot \mathrm{ha}^{-1}$ & 0,4 & 0,8 & 0,3 & 0,4 & 0,2 & 0,5 & 0,3 & 2,9 \\
\hline $\mathrm{Cd}$ & $\mathrm{g} \cdot \mathrm{ha}^{-1}$ & 0,2 & 0,5 & $<0,2$ & 0,3 & $<0,2$ & 0,3 & 0,3 & 1,6 \\
\hline
\end{tabular}

Megjegyzés: Az As, Hg és Se mennyisége általában $\mathrm{g} \cdot \mathrm{ha}^{-1}$ méréshatár alatti 
A négy év alatt a hét kaszálás szénája $756 \mathrm{~kg} \mathrm{~N}, 491 \mathrm{~kg} \mathrm{~K}, 454 \mathrm{~kg} \mathrm{Ca}, 78 \mathrm{~kg} \mathrm{P}$, $69 \mathrm{~kg}$ elemi Mg és $61 \mathrm{~kg} \mathrm{~S}$ elemet akkumulált. Ami a mikroelemeket illeti, a Fe mintegy $5 \mathrm{~kg}$, az Al $3 \mathrm{~kg}$, a Mn és Sr 1,5-1,5 kg mennyiségünek adódott. A négy év alatt felvett B 632 g, a Zn 333 g, a Cu 144 g, a Ni 36 g, a Mo 19 g, a Cr és az Pb 10 $\mathrm{g}$, a Co $3 \mathrm{~g}$ és a Cd 1,6 g tömeget tett ki. Az As, Hg, Se mennyisége általában a $\mathrm{g} \cdot$ ha $^{-1}$ méréshatár alatt maradt (9. táblázat).

Az $1 \mathrm{t}$ szénatermés átlagos, fajlagos elemtartalma a 9. táblázat adatai alapján: 34 $\mathrm{kg} \mathrm{N}, 22 \mathrm{~kg} \mathrm{~K}\left(26 \mathrm{~kg} \mathrm{~K}_{2} \mathrm{O}\right), 20 \mathrm{~kg} \mathrm{Ca}(28 \mathrm{~kg} \mathrm{CaO}), 3,5 \mathrm{~kg} \mathrm{P}\left(8 \mathrm{~kg} \mathrm{P}_{2} \mathrm{O}_{5}\right), 3,1 \mathrm{~kg}$ $\mathrm{Mg}(5 \mathrm{~kg} \mathrm{MgO}), 2,7 \mathrm{~kg} \mathrm{~S}, 216 \mathrm{~g} \mathrm{Fe}, 149 \mathrm{~g} \mathrm{Al}, 66 \mathrm{~g} \mathrm{Mn}, 70 \mathrm{~g} \mathrm{Sr}, 16 \mathrm{~g} \mathrm{Na}, 28 \mathrm{~g} \mathrm{~B}$, $15 \mathrm{~g} \mathrm{Zn}, 6-7 \mathrm{~g}$ Cu és 4-5 g Ba mennyiségnek adódott ezen a talajon.

\section{0. táblázat}

A légszáraz tarka koronafürt, a lucernaszéna és a pillangósnélküli 0 és $300 \mathrm{~kg} \cdot \mathrm{ha}^{-1} \cdot \mathrm{év}^{-1} \mathrm{~N}$ trágyázott gyepszéna takarmányértékének összehasonlítása (Dr. Győri Zoltán vizsgálatai, DATE, Debrecen; 1999)

\begin{tabular}{|c|c|c|c|c|}
\hline $\begin{array}{c}\text { (1) } \\
\text { Mért } \\
\text { jellemző }\end{array}$ & $\begin{array}{c}\text { (2) } \\
\text { Lucerna } \\
2004.07 .12 .\end{array}$ & $\begin{array}{c}\text { (3) } \\
\text { Koronafürt } \\
2004.05 .19 .\end{array}$ & $\begin{array}{c}(4) \\
\text { Koronafürt } \\
\text { a lucerna \%-ában }\end{array}$ & $\begin{array}{c}\text { (5) } \\
\text { Gyepszéna } \\
2001.05 .23 .\end{array}$ \\
\hline \multicolumn{5}{|c|}{ A. Légszáraz anyag, \% } \\
\hline a) Ny.fehérje & 18,8 & 24,2 & 129 & $6,4-18,3$ \\
\hline b) Ny.rost & 16,8 & 21,1 & 126 & $30,3-32,2$ \\
\hline c) Ny.hamu & 9,4 & 8,4 & 89 & $6,4-8,6$ \\
\hline d) Ny.zsír & 2,2 & 1,6 & 73 & $1,8-2,6$ \\
\hline \multicolumn{5}{|c|}{ B. Aminósav, $g \cdot 100 g^{-l}$ fehérje } \\
\hline CYS & 0,11 & 0,02 & 18 & $0,02-0,09$ \\
\hline MET & 0,18 & 0,15 & 83 & $0,07-0,18$ \\
\hline TYR & 0,71 & 0,61 & 86 & $0,26-0,45$ \\
\hline GLY & 1,12 & 0,98 & 88 & $0,54-1,85$ \\
\hline THR & 1,00 & 0,88 & 88 & $0,46-0,98$ \\
\hline LEU & 1,61 & 1,44 & 89 & $0,69-1,66$ \\
\hline GLU & 2,47 & 2,27 & 92 & $1,08-2,65$ \\
\hline LYS & 1,50 & 1,40 & 93 & $0,67-1,07$ \\
\hline ALA & 1,32 & 1,24 & 94 & $0,55-0,40$ \\
\hline ILE & 0,79 & 0,75 & 95 & $0,33-0,73$ \\
\hline SER & 1,07 & 1,08 & 101 & $0,33-0,72$ \\
\hline PHE & 1,10 & 1,12 & 102 & $0,42-1,01$ \\
\hline VAL & 1,00 & 1,08 & 108 & $0,56-1,13$ \\
\hline HIS & 0,95 & 1,04 & 109 & $0,38-1,12$ \\
\hline ARG & 0,87 & 0,96 & 110 & $0,38-0,89$ \\
\hline PRO & 0,31 & 0,72 & 232 & $0,26-0,72$ \\
\hline ASP & 2,66 & 8,48 & 319 & $0,79-1,98$ \\
\hline TRY & - & - & - & $0,15-0,07$ \\
\hline
\end{tabular}


Adataink felhasználhatók a tervezett termés elemigényének számításában a szaktanácsadásban. A nagy fajlagos $\mathrm{N}$-tartalom természetesen nem jelent trágyaigényt, amennyiben a koronafürt N-igényét alapvetően a légkörből fedezheti.

Megjegyezzük, hogy érthetetlen miért ajánl a növénytermesztő az ,igen jól” ellátott talajon, a $180-450 \mathrm{mg} \cdot \mathrm{kg}^{-1} \mathrm{AL}-\mathrm{P}_{2} \mathrm{O}_{5}$, illetve $180-650 \mathrm{mg} \cdot \mathrm{kg}^{-1} \mathrm{AL}-\mathrm{K}_{2} \mathrm{O}$ mellett (mely valójában a „káros” túlsúlyt jelöli), még 12-23 kg $\mathrm{P}_{2} \mathrm{O}_{5}$, illetve 11-13 kg $\mathrm{K}_{2} \mathrm{O}$ hatóanyagot minden tonna tervezett szénatermés előállításához ott, ahol a P- és K-adagolást szüneteltetni kellene a talajtermékenység helyreállítása érdekében (ANTAL, 2005).

A 10. táblázatban a koronafürt, a lucernaszéna és a pillangós nélküli gyep takarmányértékének mért jellemzőit hasonlítjuk össze GYőRI (1999) vizsgálatai alapján. A pillangós nélküli gyepszéna minimum értékei a $0 \mathrm{~kg} \mathrm{~N} \cdot \mathrm{ha}^{-1} \cdot \mathrm{e}^{-1}$, maximum értékei a $300 \mathrm{~kg} \mathrm{~N} \cdot \mathrm{ha}^{-1} \cdot \mathrm{ev}^{-1}$ parcellákat reprezentálják a mészlepedékes csernozjom talajon.

A nyersfehérje, nyersrost, nyershamu és a nyerszsír a légszáraz széna \%-ában, míg az aminosavak a fehérje \%-ában vannak megadva. A koronafürt takarmányértékének mutatóit a standardnak tekintett lucerna \%-ában is feltüntettük, a jobb áttekinthetőség céljából. Látható, hogy a lucernához viszonyítva a koronafürt széna fehérjetartalma rendkívüli szegény cisztin, illetve rendkívül gazdag prolamin és asparagin aminosavakban. A többi vizsgált aminosavat tekintve az eltérés nem jelentős, 10 és $20 \%$ közötti. A pillangós nélküli hétkomponensü gyepszéna összetétele tág határok között ingadozott a N-kínálat függvényében. A bőséges $\mathrm{N}$ trágyázással a gyepszéna nyersfehérje és nyershamu \%-a elérheti a pillangós lucerna és a koronafürt szénákban mért értékeket. A fehérje aminosav-tartalma a Nadagolással akár a többszörösére is nőhet a gyepszénában. Ez alól kivételt a triptofán jelentett, melynek koncentrációja a bőséges $\mathrm{N}(\mathrm{PK})$ kínálattal a felére csökkent.

A többi vizsgált aminosav mennyisége a fehérjében gyakran megközelítette vagy el is érte a standard lucerna fehérjében mértet, sőt, a GLY, LEU, GLU, ILE, VAL és HIS aminosavak mennyisége a N-trágyázással meg is haladta a lucerna fehérje aminosav-tartalom értékeit (10. táblázat).

\section{Összefoglalás}

Az MTA TAKI Nagyhörcsöki Kísérleti Telepén (Mezöföld), mészlepedékes csernozjom vályogtalajon vizsgáltuk a $\mathrm{K}, \mathrm{B}$ és $\mathrm{Sr}$ elemek közötti kölcsönhatásokat 1998 és 2004 között. A K-szinteket megismételt 0,1000 és $2000 \mathrm{~kg} \mathrm{~K}_{2} \mathrm{O} \cdot \mathrm{ha}^{-1}$, a Bszinteket megismételt $0,20,40,60 \mathrm{~kg} \mathrm{~B} \cdot \mathrm{ha}^{-1}$ és a Sr-szinteket $67 \mathrm{~kg} \mathrm{Sr} \cdot \mathrm{ha}^{-1}$ adaggal állítottuk be. Mütrágyaként $60 \%$-os KCl-ot, $11 \%$-os bóraxot és $33 \%$-os $\mathrm{SrCl}_{2} \times 6 \mathrm{H}_{2} \mathrm{O}$ sót alkalmaztunk. Főparcellánként 3K-kezelés, alparcellánként 4B-kezelés, alalparcellánként $2 \mathrm{Sr}$-kezelés szolgált ( 24 kezelés x 3 ismétlésben $=72$ parcella), osztott parcellás elrendezésben.

A kísérlet beállításakor (1987 öszén) a szántott réteg $5 \% \mathrm{CaCO}_{3}$-ot, $3 \%$ humuszt és $20 \%$ agyagot tartalmazott. $\mathrm{A} \mathrm{pH}\left(\mathrm{H}_{2} \mathrm{O}\right) 7,8 \mathrm{a} \mathrm{pH}(\mathrm{KCl})$ pedig 7,3 volt. $\mathrm{Az} \mathrm{AL}-\mathrm{K}_{2} \mathrm{O}$ 
180-200, az AL- $\mathrm{P}_{2} \mathrm{O}_{5} 100-120$, a KCl-oldható Mg 110-150, a KCl+EDTA oldható Mn 60-80, a Cu és Zn 1-2 és a B $0,7 \mathrm{mg} \cdot \mathrm{kg}^{-1}$ értékkel volt jellemezhetö. A termöhely kielégítő $\mathrm{K}$-, Ca-, B- és $\mathrm{Mg}$-; közepes $\mathrm{N}$ - és $\mathrm{P}$-; valamint gyenge $\mathrm{Zn}$ - és $\mathrm{Cu}$ ellátottságú. A talajvíz szintje 13-15 m mélyen található, a terület aszályérzékeny. Az átlagos középhőmérséklet $11^{\circ} \mathrm{C}$, az éves csapadékösszeg 400 és $600 \mathrm{~mm}$ közötti egyenetlen eloszlással.

A főbb megállapítások és levonható tanulságok az alábbiak:

- Ezen a káliummal és bórral eredetileg egyaránt kielégítően ellátott talajon, a kísérlet 13. évére, az $\mathrm{AL}-\mathrm{K}_{2} \mathrm{O}$ tartalom a szántott rétegben az eredeti $180-200$ $\mathrm{mg} \cdot \mathrm{kg}^{-1}$ értékröl $140 \mathrm{mg} \cdot \mathrm{kg}^{-1}$-ra csökkent. A K-hatások idővel kifejezettebbekké váltak, a koronafürt a négy év alatti hét kaszálással $572 \mathrm{~kg} \mathrm{~K}_{2} \mathrm{O} \cdot \mathrm{ha}^{-1}$ mennyiséggel szegényítette a talajt. A K-kontrollhoz képest a 2. kaszálás 2004-ben már $10 \mathrm{t} \cdot \mathrm{ha}^{-1}$ zöld, illetve $1 \mathrm{t} \cdot \mathrm{ha}^{-1}$ légszáraz szénatöbbletet adott, a zöldtermés szárazanyag tartalmát átlagosan 2\%-kal mérsékelte. A B- és a Sr-kezelések a termés tömegét igazolhatóan nem befolyásolták. A négy év, illetve a hét kaszálás összesen 110-120 $\mathrm{t} \cdot \mathrm{ha}^{-1}$ friss, illetve 21-24 $\mathrm{t} \cdot \mathrm{ha}^{-1}$ légszáraz szénahozamot adott.

- A K-trágyázás gátolta a $\mathrm{Ca}, \mathrm{Mg}, \mathrm{Na}$ és $\mathrm{Sr}$ kationok beépülését a szénába a $\mathrm{K}$ tartalom egyidejü növelése mellett. A B-trágyázás még 10-14 év után is megtöbbszörözte a széna B-tartalmát. A kis terméstömegü, elöregedő szénában a Bakkumuláció elérte a $372 \mathrm{mg} \cdot \mathrm{kg}^{-1}$ mennyiséget. A 9-12 évvel korábban adott 67 $\mathrm{kg} \cdot \mathrm{ha}^{-1} \mathrm{Sr}$-adag általában igazolhatóan mérsékelte az antagonista $\mathrm{Na}$ felvételét.

- A lucerna zöldbimbós állományára az irodalomban közölt és általunk is ellenörzött 2-5\% N; 2-4\% K; $1-3 \% \mathrm{Ca} ; 0,3-0,8 \% \mathrm{Mg} ; 0,3-0,7 \% \mathrm{P}$ és S, illetve 30-200 $\mathrm{mg} \cdot \mathrm{kg}^{-1} \mathrm{Fe}$ és Al; 30-100 mg Mn $\mathrm{kg}^{-1}, 35-80 \mathrm{mg} \mathrm{B} \cdot \mathrm{kg}^{-1}, 20-70 \mathrm{mg} \mathrm{Zn} \cdot \mathrm{kg}^{-1}, 5-15$ $\mathrm{mg} \mathrm{Cu} \cdot \mathrm{kg}^{-1}$ és $0,5-2,0 \mathrm{mg} \mathrm{Mo} \cdot \mathrm{kg}^{-1}$ optimumok megfelelőek lehetnek a koronafürt tápláltsági állapotának megítélésére is.

- Az 1 t szénatermés átlagos, fajlagos elemtartalma $34 \mathrm{~kg} \mathrm{~N}, 22 \mathrm{~kg} \mathrm{~K}(26 \mathrm{~kg}$ $\left.\mathrm{K}_{2} \mathrm{O}\right), 20 \mathrm{~kg} \mathrm{Ca}(28 \mathrm{~kg} \mathrm{CaO}), 3,5 \mathrm{~kg} \mathrm{P}\left(8 \mathrm{~kg} \mathrm{P}_{2} \mathrm{O}_{5}\right), 3,1 \mathrm{~kg} \mathrm{Mg}(5 \mathrm{~kg} \mathrm{MgO}), 2,7 \mathrm{~kg}$ S, 216 g Fe, 149 g Al, 66 g Mn, 70 g Sr, 16 g Na, 28 g B, 15 g Zn, 6-7 g Cu és 4-5 $\mathrm{g}$ Ba mennyiséget tett ki ezen a talajon.

Adataink felhasználhatók a szaktanácsadásban, a tervezett termés elemigény számításakor, figyelembe véve, hogy a N-t alapvetően a légköri megkötés fedezheti, illetve a $\mathrm{Zn}$ és $\mathrm{Cu}$ fajlagosok mérsékeltek a termőhely gyenge $\mathrm{Zn}$ - és $\mathrm{Cu}$ ellátottsága miatt.

- Ami a koronafürt széna takarmányértékét illeti megállapítottuk, hogy a standard lucerna összetételhez viszonyítva a nyersfehérje 29 , a nyersrost $26 \%$-kal haladta meg a lucernáét, míg a nyershamu 11, a nyerszsír 27\%-kal volt kevesebb. A koronafürt és a lucerna aminosav tartalmát (17 aminosav) összevetve azt találtuk, hogy a koronafürt szénafehérje rendkívül szegény cisztin (CYS), illetve rendkívül gazdag prolamin (PRO) és asparagin (ASP) aminosavakban. A többi aminosav lényeges eltérést nem mutat (10-20\%) a két hüvelyes takarmánynövényben.

Összességében megállapítható, hogy a koronafürt versenyképes lehet a lucernával mind a szénahozamát, mind a takarmányértékét tekintve, különösen gyengébb talajokon. 
Kulcsszavak: Kálium, bór, stroncium kezelés, koronafürt, amoninosavak, elemtartalom

\section{Irodalom}

ANONYM, 1985. Kompolti Tarka koronafürt Telepítési Útmutató. GATE Mezőgazdasági Kutatóintézete. Kompolt.

ANTAL J., 2000. Növénytermesztők Zsebkönyve. Mezőgazdasági Kiadó. Budapest.

ANTAL J. (Szerk.), 2005. Növénytermesztéstan 1-2. Mezőgazda Kiadó. Budapest

BARANYAi F., FEKETE A. \& KovÁCS I., 1987. A magyarországi talajtápanyagvizsgálatok eredményei. Mezőgazdasági Kiadó. Budapest.

Bergmann, W., 1992. Nutritional Disorders of Plants. Gustav Fischer Verlag. JenaStuttgart-New York.

BóCSA I., 1994. A tarka koronafürt. Akadémia Kiadó. Budapest.

BócSA I., KRISZTiÁN J., KADLICSKÓ B. \& MÁTÉ A., 1980. Kísérletek a tarka koronafürt (Coronilla varia L.) magyarországi bevezetésére. Növénytermelés. 29. (2) 115123.

EgNÉR, H., RieHM, H. \& DOMingO, W. R., 1960. Untersuchungen über die chemische Bodenanalyse als Grundlage für die Beurteilung des Nährstoffzustandes der Böden. II. K. Lantbr. Högsk. Ann. 26.199-215.

Grace, F. V. \& GraU, A. F., 1952. Crownvetch-promising new cover crop. Crops and Soils. 4. (9) 22-25.

HENSON, P. R., 1963. Crownvetch- a soil conserving legume and a potential pasture and hay plant. U.S. Dept. Agr. Res. Ser. ARS 34-53. USA.

GYÖRI Z., 1999. A termesztési tényezők hatása egyes gabonafélék és maghüvelyesek minőségére. MTA Doktori Értekezés. Debrecen.

KÁDÁR I., 2009. Mütrágyázás hatása a lucerna (Medicago sativa L.) elemtartalmára karbonátos homoktalajon 2001-2004 között. Agrokémia és Talajtan. 58. (2) 265280.

KÁDÁR I., 2011. A kálium és a bór elemek közötti kölcsönhatások vizsgálata tartamkísérletben. Agrokémia és Talajtan. 60. (1) 161-178.

KÁDÁR I., 2012. A kálium, bór és a stroncium elemek közötti kölcsönhatások vizsgálata lucernában.Agrokémia és Talajtan. 61. (1) 133-150.

KÁDÁR I. \& CSATHÓ P., 2011. A kálium és a bór elemek közötti kölcsönhatások vizsgálata tavaszi repcében. Agrokémia és Talajtan. 60. (2) 359-370.

KÁDÁR I. \& CsATHÓ P., 2012. A kálium és a bór elemek közötti kölcsönhatások vizsgálata kukoricában. Növénytermelés. 61. (3) 37-57.

KJELDAHL, J., 1891. Neue Methode zur Bestimmung des Stickstoffs in organischen Körpern. Zeitschr. f. analyt. Chemie. 22. 366-382.

LAKANEN, E. \& ERVIÖ, R., 1971. A comparison of eight extractants for the determination of plant available microelements in soils. Acta Agr. Fenn. 123. 223-232.

MÁTÉ A., 1983a. A különböző talajtípusok hatása a tarka koronafürt (Coronilla varia L.) termesztési lehetőségére. Növénytermelés. 32. (3) 231-236.

MÁTÉ A., 1983b. Kísérletek a tarka koronafürt tápanyagigényének meghatározására. I. Tenyészedénykísérletek. Növénytermelés. 32. (5) 437-443. 
MÁTÉ A., 1983c. Kísérletek a tarka koronafürt tápanyagigények meghatározására. II. Szántóföldi kísérletek. Növénytermelés. 32. (6) 549-558.

MÉM NAK, 1978. A TVG tápanyagvizsgáló laboratórium módszerfüzete. MÉM Növényvédelmi és Agrokémiai Központ. Budapest.

MÉM NAK, 1979. Mütrágyázási irányelvek és üzemi számítási módszer. MÉM Növényvédelmi és Agrokémiai Központ. Budapest.

SHEARD, R. W., 1971. Edaphic aspects of crownvetch in Ontario. Univ. of Guelf. Ontario, Canada. 43-48.

SILlANPÄÄ, M., 1982. Micronutrients and the nutrient status of soils. A global study. FAO Soils Bulletin N. 48. Rome.

Simkins, C. A., Overdahl, C. J. \& Grava J., 1970. Fertilizer for alfalfa. Univ. of Minnesota. Extension Folder. 225, St. Paul, Minnesota. USA.

SiPPOLA, J. \& ERVIÖ, R., 1977. Determination of boron in soils and plants by the azomethine-H method. Finn. Chem. Lett. 1977. 138-140.

Stein W. H. \& MoORE S., 1951. Amino acid determination methods and techniques. Jounal of Biological Chemistry. 192. 663-670.

TYURIN, I. V., 1937. Organicseszkie vescsesztva pocsv. Szelhozgiz. Moszkva.

Érkezett: 2015. október 15. 


\title{
Effect of potassium, boron and strontium treatment on crown vetch (Coronilla varia $\mathbf{L}$.)
}

\author{
I. KÁDÁR \\ Department of Agricultural Chemistry, Institute for Soil Science and Agricultural Chemistry, \\ Centre for Agricultural Research, Hungarian Academy of Sciences, Budapest
}

\section{Summary}

Interactions between the elements $\mathrm{K}, \mathrm{B}$ and $\mathrm{Sr}$ were investigated on a chernozem loam soil with lime deposits at the Nagyhörcsöki Experimental Station of the institute in the Mezöföld region of Hungary between 1988 and 2004. The K and B levels were adjusted using repeated doses of 0,1000 and $2000 \mathrm{~kg} \cdot \mathrm{ha}^{-1} \mathrm{~K}_{2} \mathrm{O}$ and $0,20,40$ and 60 $\mathrm{kg} \cdot \mathrm{ha}^{-1} \mathrm{~B}$, and the Sr levels using rates of 0 and $67 \mathrm{~kg} \cdot \mathrm{ha}^{-1} \mathrm{Sr}$. The fertilisers were applied in the form of $60 \% \mathrm{KCl}, 11 \%$ borax and $33 \% \mathrm{SrCl}_{2} \times 6 \mathrm{H}_{2} \mathrm{O}$. The $3 \mathrm{~K}$ treatments formed the main plots, the $4 \mathrm{~B}$ treatments the subplots and the $2 \mathrm{Sr}$ treatments the subsubplots, giving a total of 24 treatments $\times 3$ replications on 72 plots in a split-plot design.

When the experiment was set up in autumn 1987 the ploughed layer contained 5\% $\mathrm{CaCO}_{3}, 3 \%$ humus and $20 \%$ clay, with $\mathrm{pH}\left(\mathrm{H}_{2} \mathrm{O}\right) 7.8, \mathrm{pH}(\mathrm{KCl}) 7.3$, and element contents $\left(\mathrm{mg} \mathrm{kg}^{-1}\right)$ of $180-200 \mathrm{AL}-\mathrm{K}_{2} \mathrm{O}, 100-120$ AL- $\mathrm{P}_{2} \mathrm{O}_{5}, 110-150 \mathrm{KCl}$-soluble $\mathrm{Mg}, 60$ $80 \mathrm{KCl}+$ EDTA-soluble $\mathrm{Mn}, 1-2 \mathrm{Cu}$ and $\mathrm{Zn}$, and $0.7 \mathrm{~B}$. The soil was satisfactorily supplied with $\mathrm{K}, \mathrm{Ca}, \mathrm{B}$ and $\mathrm{Mg}$, moderately well with $\mathrm{N}$ and $\mathrm{P}$, and poorly with $\mathrm{Zn}$ and $\mathrm{Cu}$. The groundwater was located at a depth of 13-15 $\mathrm{m}$ and the area was prone to drought. The mean temperature averaged $11^{\circ} \mathrm{C}$, and the annual rainfall sum was $400-600 \mathrm{~mm}$, with uneven distribution. The main conclusions drawn from the results were as follows:

- By the $13^{\text {th }}$ year of the experiment the AL-soluble $\mathrm{K}_{2} \mathrm{O}$ content in the ploughed layer, which was originally satisfactorily supplied with potassium and boron, had dropped from $180-200 \mathrm{mg} \cdot \mathrm{kg}^{-1}$ to $140 \mathrm{mg} \cdot \mathrm{kg}^{-1}$. K effects gradually became more pronounced; the seven cuts of crown vetch over the 4 years removed $572 \mathrm{~kg} \mathrm{~K}_{2} \mathrm{O} \cdot \mathrm{ha}^{-1}$ from the soil. Compared with the $\mathrm{K}$ control the $2^{\text {nd }}$ cut in 2004 gave a surplus of $10 \mathrm{t} \cdot \mathrm{ha}^{-1}$ fresh and $1 \mathrm{t} \cdot \mathrm{ha}^{-1}$ air-dry hay and the dry matter content of the fresh yield was $2 \%$ lower on average. The $\mathrm{B}$ and $\mathrm{Sr}$ treatments had no significant influence on the yield quantity. The total hay yields over the four years (seven cuts) amounted to $110-120 \mathrm{t} \cdot \mathrm{ha}^{-1}$ (fresh) and $21-24 \mathrm{t} \cdot \mathrm{ha}^{-1}$ (air-dry).

$-\mathrm{K}$ fertilisation inhibited the incorporation of $\mathrm{Ca}, \mathrm{Mg}, \mathrm{Na}$ and $\mathrm{Sr}$ cations into the hay, with a simultaneous increase in the K content. Even after 10-14 years B fertilisation resulted in a multiple increase in the $\mathrm{B}$ content of the hay. The $\mathrm{B}$ accumulation in the small yield of aging hay was as high as $372 \mathrm{mg} \cdot \mathrm{kg}^{-1}$. In most cases the $67 \mathrm{~kg} \cdot \mathrm{ha}^{-1} \mathrm{Sr}$ dose applied 9-12 years earlier significantly reduced the uptake of the antagonist element Na.

- The optimum supply levels of $2-5 \% \mathrm{~N}, 2-4 \% \mathrm{~K}, 1-3 \% \mathrm{Ca}, 0.3-0.8 \% \mathrm{Mg}, 0.3-$ $0.7 \% \mathrm{P}$ and $\mathrm{S}$, and the $\mathrm{mg} \mathrm{kg}^{-1}$ levels of $30-200 \mathrm{Fe}$ and $\mathrm{Al}, 30-100 \mathrm{Mn}, 35-80 \mathrm{~B}, 20-70$ $\mathrm{Zn}, 5-15 \mathrm{Cu}$ and $0.5-2.0 \mathrm{Mo}$, published for alfalfa in the green-bud stage and checked in the present work, could also be suitable for judging the nutrient status of crown vetch. 
- The mean/specific element contents of $1 \mathrm{t}$ hay yield were approximately $34 \mathrm{~kg} \mathrm{~N}$, $22 \mathrm{~kg} \mathrm{~K}\left(26 \mathrm{~kg} \mathrm{~K} \mathrm{~K}_{2} \mathrm{O}\right), 20 \mathrm{~kg} \mathrm{Ca}(28 \mathrm{~kg} \mathrm{CaO}), 3.5 \mathrm{~kg} \mathrm{P}\left(8 \mathrm{~kg} \mathrm{P}_{2} \mathrm{O}_{5}\right), 3.1 \mathrm{~kg} \mathrm{Mg}(5 \mathrm{~kg}$ $\mathrm{MgO}), 2.7 \mathrm{~kg} \mathrm{~S}, 216 \mathrm{~g} \mathrm{Fe}, 149 \mathrm{~g} \mathrm{Al}, 66 \mathrm{~g} \mathrm{Mn}, 70 \mathrm{~g} \mathrm{Sr}, 16 \mathrm{~g} \mathrm{Na}, 28 \mathrm{~g} \mathrm{~B}, 15 \mathrm{~g} \mathrm{Zn}, 6-7 \mathrm{~g}$ $\mathrm{Cu}$ and 4-5 $\mathrm{g}$ Ba on this soil. These data can be used by the extension service when calculating the element requirements of the planned yield. It must also be taken into consideration that crown vetch meets most of its $\mathrm{N}$ requirements by fixing atmospheric $\mathrm{N}$, while the specific contents of $\mathrm{Zn}$ and $\mathrm{Cu}$ were moderate due to the poor $\mathrm{Zn}$ and $\mathrm{Cu}$ supplies at this location.

- With regard to the feed value of crown vetch hay, the crude protein content and crude fibre content were found to exceed those of standard alfalfa hay by $29 \%$ and $26 \%$, respectively, while the crude ash and crude fat contents were $11 \%$ and $27 \%$ lower, respectively. Of the 17 amino acids analysed, the protein of crown vetch hay was found to be extremely poor in cystine (CYS), but extremely rich in prolamine (PRO) and aspartic acid (ASP). The other amino acids exhibited no significant differences (10-20\%) between the two legumes.

All in all it can be concluded that crown vetch could be competitive with alfalfa in terms of both hay yield and nutritional value, especially on poorer soils.

Table 1. Crop sequence in the long-term $\mathrm{K} \times \mathrm{B} \times \mathrm{Sr}$ experiment between 1988 and 2004 (chernozem loam soil with lime deposits, Nagyhörcsök, Mezőföld). (1) Year. (2) Plant species (rotation). (3) Variety (hybrid).

Table 2. Main agronomic operations and observations in the experiment on crown vetch between 2001 and 2004 (chernozem loam soil with lime deposits, Nagyhörcsök, Mezőföld). (1) Operations. (2) Date. (3) Methodological guidelines. a) Autumn fertilisation (NP), b) Autumn ploughing (25-30 cm), c) Spring N fertilisation, d) Harrowing, N fertiliser mixing with upper soil layer, e) Seedbed preparation, f) Sowing+seedbed compaction, g) Sowing+seedbed compaction (repeated sowing), h) Bonitation for crop development stage, i) Mowing (mowing machine), j) Drying and grinding of the samples. Note: Variety: Kompolti crown vetch, sown at a depth of 1-2 $\mathrm{cm}$ with a row distance of $24 \mathrm{~cm}, 120 \mathrm{seeds} \cdot \mathrm{m}^{-1}$, i.e. $15 \mathrm{~kg}$ seed $\cdot \mathrm{ha}^{-1}$.

Table 3. Monthly and annual rainfall sums between 2000 and 2004, mm (chernozem loam soil with lime deposits, Nagyhörcsök, Mezőföld). (1) Months. (2) Years. (3) Longterm mean. a) Total. Note: * 48-years mean, observed at the research station.

Table 4. Effect of $\mathrm{K}$ supplies on the yield of crown vetch per cut (chernozem loam soil with lime deposits, Nagyhörcsök, Mezőföld). (1) Total (7 cuts). A. Green yield, $\mathrm{t} \cdot \mathrm{ha}^{-1}$. B. Air-dry material, \%. C. Air-dry hay, $\mathrm{t} \cdot \mathrm{ha}^{-1}$. Note: AL-soluble $\mathrm{K}_{2} \mathrm{O}$ content analysed in 2000 (ploughed layer).

Table 5. Effect of $\mathrm{K}$ supplies on the $\mathrm{K}, \mathrm{Ca}, \mathrm{Mg}$, $\mathrm{Na}$ and $\mathrm{Sr}$ contents of air-dry crown vetch (chernozem loam soil with lime deposits, Nagyhörcsök, Mezöföld). a) $\operatorname{LSD}_{5 \%}$; b) Mean.

Table 6. Effect of B treatments on the B content, $\mathrm{mg} \cdot \mathrm{kg}^{-1}$ ) of crown vetch (chernozem loam soil with lime deposits, Nagyhörcsök, Mezőföld). (1) B rate. a) $\operatorname{LSD}_{5 \%}$, b) Mean.

Table 7. Effect of Sr treatment on the Na content, $\mathrm{mg} \cdot \mathrm{kg}^{-1}$ ) of crown vetch (chernozem loam soil with lime deposits, Nagyhörcsök, Mezőföld). (1) Sr rate. a) $\operatorname{LSD}_{5 \%}$, b) Mean.

Table 8. Mean composition of air-dry crown vetch (chernozem loam soil with lime deposits, Nagyhörcsök, Mezőföld). (1) Element symbol. (2) Units. 
Table 9. Mean air-dry yield and element uptake of crown vetch per cut, 2001-2004 (chernozem loam soil with lime deposits, Nagyhörcsök, Mezőföld). (1) Element symbol. (2) Units. (3) Total (7 cuts). a) Hay. Note: As, Hg and Se were generally below the $\mathrm{g} \cdot \mathrm{ha}^{-1}$ detection limit.

Table 10. Comparison of the feed value of air-dry crown vetch, alfalfa hay and hay from non-leguminous swards fertilised with 0 and $300 \mathrm{~kg} \mathrm{ha}^{-1}$ year $^{-1} \mathrm{~N}$ (analysis made by Dr Zoltán Győri, University of Debrecen; 1999). (1) Measured parameter. (2) Alfalfa. (3) Crown vetch. (4) Crown vetch as a \% of alfalfa. (5) Grass hay. A. Air-dry material, \%. B. Amino acid, $\mathrm{g} \cdot 100 \mathrm{~g}^{-1}$ protein. 